\title{
Analysis on the Current Situation and Practical Strategies of Safety Education for Contemporary College Students
}

\author{
Chengcheng Wang \\ Tonghua Normal University \\ 950 Yucai Road, Tonghua, Jilin, China, 134001
}

\begin{abstract}
The safety education of college students not only protects the healthy growth of individuals and perfects the ideological education system, but also maintains the harmony and stability of the campus and the society.This paper, through the analysis of the current situation of safety education for college students, puts forward the establishment of safety education system and related strategies.
\end{abstract}

Keywords-safety education for college students; current situation; analysis of strategies

\section{INTRODUCTION}

In recent years, it has become common phenomenon that college students have been involved in illegal pyramid selling, fighting, gambling, drunk driving and other illegal activities. In addition,cases that college students get deceived and victimized in happen occasionally. All this not only brings harm to themselves and their family, but also cause huge losses for the society. Therefore, great attention has been drawn on the Safety Education for College Students.

\section{THE NECESSITY OF SAFETY EDUCATION FOR COLLEGE STUDENTS}

Safety education for college students refers that the university administrators and educators, based onthe laws, regulations, principles and policies of the party and the state, takethe overall improvement of the comprehensive quality of college students as the goal, and set safety responsibility, safety awareness and safety knowledge as the main content of the education, through the entrance education, curriculum education and daily education and many other means. It is an education to enhance the safety awareness of college students, to make college students master comprehensive and systematic safety knowledge, to improve their security awareness and self-protection skills. It is also a necessary education to let college students adapt to university life better and help them integrate into the society in the future. ${ }^{1}$

\footnotetext{
${ }^{1}$ Chen Mingle.2011."Value Consideration and Path Selection of Students' Safety Education" [J]. Economic Research Guide.
}

\section{A. Protect Personal Healthy Growth}

Looking through the various cases that occurred inside and outside college campuses in recent years, for different reasons, we find that all those cases are caused by college students' lack of social experience, carelessness, weak self-protection awareness and prevention awareness, poor mental capacity. Therefore, safety education in colleges and universities can improve students' self-protection and safety awareness, strengthen preventive awareness,through psychological counseling, and encourage students to protect themselves by the use of laws, regulations and other legitimate methods, to avoid personal injury and protect personal healthy growth.

\section{B. Maintain the Harmony of Campus}

With the development of the society and the increase of demand, university campuses are no longer closed, but widely open and diversified, so there will be many hidden dangers. From the external point of view, in recent years, there are many illegal pyramid selling, cults, political agitating organizations penetrating into the campus, which has impact on the harmony and stability of campuses. Effective safety education can sound the alarm for college students to avoid the occurrence of the hidden dangers in the campus and maintain the harmony and stability of the campus. From the internal point of view, the number and the proportion of college students suffering from mental diseases has increased year by year; the number of various hidden dangers and safety incidents that college students are facinghas increased constantly. All those show to us that the current situation of the safety of college students is now not very optimistic, which urgently requires us to carry out effective safety education to exclude hidden dangers and safety incidents for college students.

\section{Improve the System of College Students' Ideological Education}

At the meantime of generally improving comprehensive quality of college students and strengthening the ideological and political education, cultivate the healthy personality of college students, and carry out safety education for college students asa compulsory course. In the real social life, the personal safety and thehealthy personality of college students are the foundation of the cultivation of talents and the 
ideological education for college students; without personal safetyand healthy personality, all other things are useless, and everything you do will be in vain. Therefore, the safety education for college students is an inevitable requirement to improve the ideological education system and cultivate highquality talents.

\section{CURRENT SituATION OF SAFETY EDUCATION IN COLLEGES AND UNIVERSITIES}

Colleges and universities set up the security department, and carry out the patrol system, to provide maximum protection for the safety of students and the campus. Surrounding with campus security, fire-proofing, thievery prevention, safety education will be carried out regularly each year in colleges and universities, to sound the alarm for college students.

\section{A. Safety Education Does Exist, But Has No Formed System}

Colleges the universities all have safety education taught through the Internet or in combination with the entrance education. However, there are no sound institutions and stable teaching groups, no specific departments to undertake teaching tasks and teaching responsibilities. There are different set-ups ofsafety education institutions for college students. In some colleges and universities, safety educationis under the responsibility of the security department; some are under the responsibility of university hospitals; some are of college students' mental health education centers. The powers and responsibilities of various departments are not clear, resulting in educational confusion and no system.

\section{B. Colleges and Universities Have Paid Much Attention on Safety Management, But Not on the Prior Education and Prevention Work}

With the progress and development of the society, the concept of "people-oriented, attention to life, attention to safety" enjoys popular support, so many colleges and universities also implement accountability system, and the department heads,in order to prevent safety incidents, pay great attention to the safety management. The safety management is well done by colleges and universities; once safety incidents happen, great attention will be paid to the afterwards treatment. The work of safety education for students is neglected, which affects the quality of safety education, and students, and doesn't improve the sense of selfsafetyof students because of neglecting to mobilize the active initiative of them. The safety incidents of college students are now still theat the afterwards treatment stage, haven't got into the education-oriented prior prevention stage.

\section{The Content of Safety Education Is Disconnected with Practical Study Life}

Safety education is widely promoted among colleges and universities, but it doesn't keep pace with the development of the society; the teaching content is out of date, and doesn't keep pace with the tricks of cheaters. Thus, many students think safety education is no more than a platitude so that they have an aversion to it, which limits safety education not to make the best effect.

\section{ANALYSIS ON ThE EXISTING PROBLEMS}

\section{A. Education Ideas and Safety Education Content Fall Behind}

Prior prevention is better than remedy. We should change theway of thinking, and transform the afterwards treatment into prior prevention tostrengthen safety education. Safety education is a regular education work in colleges and universities. With the development of the society, the contents of campus security are quite different. However, many schools partially consider safety education as the education of legal publicity and other safety protection knowledge of public security, traffic and fire prevention, etc. National security education, escape skills, mental health education, network security, food safety, medical security, social security, employment safety education, protection of rights and interests are not included in the scope of safety education. The content of safety education is relatively lagging behind, combining little with the development of the times; the list of new hidden dangers hasn't been updated, so the scope of education is limited.

\section{B. The Attention to Safety Education Is Not Well Paid, and the System Is Not Carried out in Place}

Some colleges and universities do not pay enough attention to safety education, and there is no uniform teaching material for learning andno enough funds to support the safety education, which makes it have no guarantee of the training personnel, the content, time, and the effect, forming no effective education system.

The main body of safety education for college students are college counselors. Counselors, as multitaskers, have many affairs and much work. They teach safety education only by watching, reading and listening. They don't pay enough attention to safety education and they are not professional enough. Safety education should be classified, and be effectively explained and demonstrated by invited professionals. For example, fire proofing andthievery prevention should be explained by the fire brigade or public security personnel, and psychological disease prevention should be taught by teachers of psychological research profession and so on.

\section{The Responsibility for Safety Education Is Not Clear}

The responsibility of different aspects of the safety education in most colleges and universities is taken by different departments; some of the aspects are taken care by students and some by security departments. Different departments don't cooperate with each other very often, but work separately, which can't perform the cooperating power of education and form an education system.

\section{The Way of Safety Education Is Traditional}

Right now, safety education in colleges and universities mainly relies on methods like lecture, panel, newspaper, etc., 
but less on new media like the internet and phones; book more than animation and practice. More new education methods should be developed. Bind the internet with safety education to let students read and learn willingly with more attention.

\section{E. The Effect of Safety Education Is Not Obvious}

The reason why the effect of safety education is not obvious can blame on the scarcity of the attention on safety education, the lack of money and creativity, and the formalistic implementation, with inappropriate ways and methods.

\section{The Practical Strategies Of The Safety EDUCATION FOR COLLEGE STUDENTS}

\section{A. Draw More Attention from the Society and Universities on the Safety Education for College Students}

College students are the new energy of the society and the future of the country. The carry-out of the safety education for college students can not only protect personal safety and promote family harmony, but also maintain the stability of the campus, which is the need of inputting qualified talents for the community. Thus, the improvement of safety education for college students will not only enhance the self-protection ability of college students, to avoid students committing crimes themselves, but also to ensure that college students will not be subject to the violations of life and property caused by lawbreakers. Therefore, safe education for college students should be paid great attention by the society and universities.

\section{B. Complete the System of the Safety Education for College Students}

The responsibility of establishing safety education system for college students should be taken by the main leaders in schools; the main responsible departments should be made sure to finish the related work with cooperation of related departments. Safety education for college students should be set as a compulsory course, to complete the credit system. Set up positions of full-time and part-time security content lecturers; hire social professionals to teach relevant content; enhance the professional safety knowledge of college counsellors; increase supervision; train core students to set up echelons of safety education system during its publicity and promotion processes, which will form a new situationthat all members act from top to bottom as one, and overall control of all members should be taken.

\section{Apply Teaching Methods with the Combination of Modernization and Practice.}

The effective educational methods with the combination of practice and modernization are widely used in the teaching methods. Apply Wechat, Weibo and micro-class, micro-video and many other modern means to safety education, which makes the promotion of a wide range, in a short time, with fast spread-speed and low cost, easy to accept and effective. In addition to theoretical educational methods, safety education should also carry out practical education, such as escape skill trainings, fire drills, public security emergency drills, etc.

\section{Implement Safety Education in Different Time Stages}

Students in different stages have different concerns, sodividing the safety education into different time stages can meet the needs of different periods, and achieve better effect of the safety education. For example, mental health education and basic educations like legal publicity, public security, traffic and fire-fightingeducations, should be put into the entrance education. During the early period of employment, preemployment safety education should be carried out.

\section{E. Set up Safety Education Files}

Setting up safety education files is to build up the tracking and feedback systems of important students during important periods to avoid the occurrence of tragedies in the campus.

\section{CONCLUSION}

The safety education in colleges and universities can enhance the self-protection and safety awareness of students, and strengthen defensive psychology. It can also, by psychological counseling, encourage students to use the law, regulations and other legitimate ways to protect themselves, and avoid personal injury to protect their own healthy growth,reducing the occurrence of the campus tragedies.

\section{REFERENCES}

[1] Chen Mingle.2011."Value Consideration and Path Selection of Students' Safety Education" [J]. Economic Research Guide.

[2] Liang Shashan. 2009. “ Deficiency of College Students' Safety Education and Construction of University Safety Management.” [J]. Journal of Inner Mongolia Normal University.

[3] Bao Caijuan.2009."Thoughts on Strengthening the Safety Education of College Students" [J].Modern Business Trade Industry.

[4] Jiang Xianing.2011."Thoughts on the Problems of College Students Safety Education" [J].Journal of Yangzhou University.

[5] Li Nan, etc.2005. "Serious Considerations on College Students' Safety Education"'J]. Journal of China Safety Science.

[6] Yang Nengshan.2007. "College Safety Education - a Compulsory Course of Ideological and Political Education for College Students" [J]. Hunan Social Sciences.

[7] Wei Qingxin.2009."Practice and Exploration of the Strengthening and Improving College Students' Safety Education in the New Period" [J]. Journal of China Safety Science. 